Emily Finer, University of St Andrews

Dombey in Zhitomir, Pip in Taganrog: Reading Dickens 'as if for life' in Russia

\begin{abstract}
$\underline{\text { Abstract }}$
Many Russian writers have been eager to demonstrate their intense childhood attachment to the novels of Charles Dickens. This essay focuses on the narrative strategies used by Vladimir Korolenko (1853-1921) and Nelli Morozova (1924-2015) in their autobiographies to convey the importance of reading Dickens in their formation as writers. It argues that David Copperfield offers a useful model for understanding how Korolenko and Morozova write about reading, and that, rather than distancing Dickens and his characters from their global readership, translations increase proximity and facilitate empathetic readings.
\end{abstract}

\title{
Dombey in Zhitomir, Pip in Taganrog: Reading Dickens 'as if for life' in Russia
}

It is not surprising that authors describe their early immersion in fictional worlds as positive and even therapeutic in their autobiographies. This essay examines three autobiographical texts, from England, the Russian Empire, and the Soviet Union, focusing on the narrative strategies used to write about childhood reading. In David Copperfield (1850), Charles Dickens describes Davey's early interaction with novels as an experience both escapist and comforting. ${ }^{1}$ Vladimir Korolenko's short autobiographical story, 'My First Acquaintance with Dickens' (1912), portrays his first encounter with a translation of Dombey and Son as a catalyst in his development as a reader. ${ }^{2}$ Nelli Morozova structures her entire

\footnotetext{
${ }^{1}$ Charles Dickens, David Copperfield (London: Nonesuch Press, 1937), p. 54.

${ }^{2}$ V. Korolenko, Moe pervoe znakomstvo s Dikkensom (1912) in Sobranie sochinenii v 6 tomakh (Moscow:
} 
autobiography, My Passion for Dickens: A Family Chronicle (1990), around readings and rereadings of Dickens's novels in Russian. ${ }^{3}$ All represent their relationships with characters or authors to be as valuable as actual friendships, to have the potential to be sustained over a lifetime. I borrow the phrase 'reading as if for life' from David Copperfield to refer to instances where a reader's interactions with a text, its characters, and its author, are so meaningful that they are prolonged long after reading has been completed. The phrase points to the way in which books offer their readers alternative lives to their own; it also complements tropes in which books provide sustenance to a hungry reader. When we read an autobiographical text where the author describes 'reading as if for life' in childhood, we are aware that this reader has become an adult who makes a living by writing. In this case, a life cycle can be observed in which readers become writers who generate more readers, who, in turn, may become writers. Dickens, Korolenko, and Morozova all offer accounts of how they began to 'read as if for life' as children and wrote for a living as adults.

Why these three writers? Korolenko and Morozova centre their autobiographical texts on their childhood reading but they also represent a phenomenon consistent across revolutions and centuries, the love of Russian readers for the novels of Charles Dickens. Russian, Soviet, and post-Soviet biographies show that Dickens has been a favourite of very different individuals: from Maxim Gorky to Yuri Gagarin, from Lev Tolstoy to Tatiana Tolstaya. ${ }^{4}$ Between the final instalment of David Copperfield in English in 1850 and

Gosudarstvennoe izdatel'stvo khudozhestvennoi literatury, 1954), V, pp. 364-371. All translations from Russian in this essay are my own.

${ }^{3}$ N. Morozova, Moe pristrastie k Dikkensu: semeinaia khronika. XX vek. (Moscow: Moskovskii rabochii, 1990).

${ }^{4}$ See: M. Gorky 'V liudiakh' in Sobranie sochinenii v 30 tomakh (Moscow: Gosudarstvennoe izdatel'stvo khudozhestvennoi literatury, 1951), XIII, p. 448; Y. Gagarin, Doroga v kosmos (Moscow: Voennogo izdatel'stva Ministserstva oborony Soiuza SSR, 1961), p.14; L. Tolstoi, Dnevniki 1847-94 in Sobranie 
Korolenko's birth in 1853, two separate Russians translations of the novel were published twice each in Russian. ${ }^{5}$ By the time Morozova was born in 1924, four different editions of the complete works were available. ${ }^{6}$ The frequency with which translations were published meant that Dickens could be read and reread in Russian over a reader's lifetime, that formative childhood relationships with Dickens and his novels could be renewed in adulthood. Korolenko and Morozova are exceptional in the extent and intensity of their attachment to Dickens: both, for example, use his name in titles to their autobiographical texts. In this essay I argue that, despite the obvious differences between the three childhoods, the description of young Davey 'reading as if for life' in David Copperfield offers a useful model for understanding how Korolenko and Morozova write about reading. The fact that Russian readers, specifically Morozova and Korolenko, read translations that move Dickens out of his time, place, and language, raises a further question. Their assertions of closeness and strong empathy for Dickens and his characters suggest that, rather than distancing the author and his characters from their global readership, translations, might, paradoxically, draw them closer together.

Korolenko and Morozova both emphasise the intense affective responses they had to Dickens's novels as children; the way empathy is represented in narrative is therefore of

sochinienii v 22 tomakh (Moscow: Khudozhestvennaia literatura, 1984) XXI, p.78; T. Tolstaia, 'Mirovaia literature: krug mnenii. Tat'iana Tolstaia, pisatel'nitsa' in Inostrannaia literatura 9 (Moscow, 1999), pp. 238247.

${ }^{5}$ Installments of David Copperfield appeared in Russian translation in Moskvitianin before the serialisation was complete in English (November, 1850). I. Katarskii, 'Dikkens i perevodchiki Moskvitianina' in Charl'z Dikkens Bibliografiia russkikh perevodov i kriticheskoi literatury na russkom iazyke 1838-1960. (Moscow: Izdatel'stvo vsesoiuznoi knizhnoi palaty, 1962), pp. 256-60.

${ }^{6}$ Iu. Fridlender, I. Katarskii, Charl'z Dikkens Bibliografiia russkikh perevodov i kriticheskoi literatury na russkom iazyke 1838-1960. (Moscow: Izdatel'stvo vsesoiuznoi knizhnoi palaty, 1962), pp. 31-35. 
particular relevance to this discussion. The focus of the foremost study on literature and empathy, Suzanne Keen's Empathy and the Novel (2007), is on spontaneous, 'real life' reader response and the narrative strategies that shape it, rather than its narrative representation in autobiography. Nonetheless, Keen's suggestion that 'many novelists call up empathy as a representational goal by mirroring it within their texts', offers a useful starting point. ${ }^{7}$ Our authors are assiduous in demonstrating that reading is a positive influence on the individual's integrity and morality. They do describe how they have mirrored the empathetic behaviour they learned from book characters in their real-world interactions. A causal relationship between empathy observed through reading and real life ethical behaviour is assumed by all three writers. Morozova's book is particularly rich in evidence that she shared Joseph Brodsky's conviction that 'for someone who has read a lot of Dickens, to shoot his like in the name of some idea is more problematic than for someone who has read no Dickens' ${ }^{8}$

However, the mirroring of empathetic behaviour from books is only one aspect of a multidirectional and dynamic system of interaction fundamental to accounts of 'reading as if for life'. In the texts to be discussed, the authors describe how, as children, they internalised and replicated the emotions of characters to the extent that they became enmeshed in their lives. They 'lived' the plot of a book in parallel with fictional characters, sharing their ignorance of what might happen next. In addition, reading allowed them to inhabit a safe fictional environment or refuge, one that could compensate for a lack of empathy in their own lives. While we might describe child readers as participating in imaginative travel to fictional worlds, neither Korolenko, Dickens, nor Morozova's accounts differentiate between travelling in the imagination and actually moving to new places for periods of time.

\footnotetext{
${ }^{7}$ S. Keen, Empathy and the Novel (Oxford: Oxford University Press, 2007), p. 121.

${ }^{8}$ Joseph Brodsky, 'Nobel Lecture, 1987,' in Brodsky's Poetics and Aesthetics, ed.s V. Polukhina, L. Loseff (New York: Macmillian Palgrave, 1990), pp. 1-12, p. 8.
} 
Furthermore, they also claim that books actively participated or intervened in their daily lives as children. The reader obviously enters and exits the text autonomously, but these accounts portray fictional characters and authors to be as mobile as their readers. They are described as accompanying their readers through life as trusted companions and guides, as imaginary friends and interlocutors. Our readers would disagree with Keen's point that 'there can be no expectancy of reciprocation involved in the aesthetic response. The very nature of fictionality renders social contracts between people and person-like characters null and void'. ${ }^{9}$ Instead, they represent social contracts between the reader and inhabitants of the fictional world as being more significant and dependable than real-life bonds. The reciprocal relationships formed between characters and authors are experienced long after the initial reading is complete; there is potential for their renewal and alteration across the reader's lifetime. 'Reading as if for life' describes a dynamic system driven by empathy, imagination, and belief.

In the preface to David Copperfield, Dickens challenged his readers to replicate his own belief in his novel: 'No one can ever believe this Narrative, in the reading, more than I have believed it in the writing'. ${ }^{10}$ Morozova and Korolenko, I will argue, answer this challenge in their autobiographical texts. After discussing the passage in David Copperfield which offers a template for describing 'reading as if for life', this essay turns to Korolenko and then Morozova's autobiographical prose, finding similarities in the way all three writers characterise themselves as empathetic and imaginative readers.

\footnotetext{
${ }^{9}$ Keen, p. 16.

${ }^{10}$ Charles Dickens, David Copperfield, p. xi.
} 
The author and narrator of David Copperfield, consistently considered Dickens's most autobiographical text, ${ }^{11}$ describes reading as having transformed his childhood:

I believe I should have been almost stupefied but for one circumstance.

It was this. My father had left a small collection of books in a little room upstairs, to which I had access (for it adjoined my own) and which nobody else in our house ever troubled. From that blessed little room, Roderick Random, Peregrine Pickle, Humphrey Clinker, Tom Jones, the Vicar of Wakefield, Don Quixote, Gil Blas, and Robinson Crusoe, came out, a glorious host, to keep me company. They kept alive my fancy, and my hope of something beyond that place and time, - they, and the Arabian Nights, and the Tales of the Genii, — and did me no harm; for whatever harm was in some of them was not there for me; I knew nothing of it. It is astonishing to me now, how I found time, in the midst of my porings and blunderings over heavier themes, to read those books as I did. It is curious to me how I could ever have consoled myself under my small troubles (which were great troubles to me), by impersonating my favourite characters in them—as I did — and by putting Mr. and Miss Murdstone into all the bad ones-which I did too. I have been Tom Jones (a child's Tom Jones, a harmless creature) for a week together. I have sustained my own idea of Roderick Random for a month at a stretch, I verily believe. I had a greedy relish for a few volumes of Voyages and Travels - I forget what, now — that were on

\footnotetext{
11 'The critical consensus has been that the novel's early chapters, drawing directly on the autobiography that Dickens abandoned in 1847, constitute a genuinely autobiographical narrative,' O. Buckton, 'The Reader Whom I Love': Homoerotic Secrets in 'David Copperfield.' ELH, vol. 64, no. 1, 1997, pp. 189-222, p.189. Russian Dickens criticism is also consistent in stating: 'Dickens always lived and suffered along with his heroes, and here [in $D C$ ] he mingled his personal reminiscences and extracts from his own history.' A. N. Annenskaia, $C h$. Dikkens ego zhizni i literaturnaia deiatel'nost' (St Petersburg: Iu. N. Erlikh, 1892), p. 58.
} 
those shelves; and for days and days I can remember to have gone about my region of our house, armed with the centre-piece out of an old set of boot-trees - the perfect realization of Captain Somebody, of the Royal British Navy, in danger of being beset by savages, and resolved to sell his life at a great price. [...]

This was my only and my constant comfort. When I think of it, the picture always rises in my mind, of a summer evening, the boys at play in the churchyard, and I sitting on my bed, reading as if for life. Every barn in the neighbourhood, every stone in the church, and every foot of the churchyard, had some association of its own, in my mind, connected with these books, and stood for some locality made famous in them. ${ }^{12}$

In this passage, reading is shown to set free the creative potential of a bored and miserable child. Dickens emphasises the unique power of books to provide Davey with emotional and imaginative nourishment, they are his 'only and my constant comfort' in childhood. In providing companionship, books act as substitutes for their former owner, the father who is missing in Davey's life. It is no wonder that the child consumes them with 'greedy relish,' or that reading is presented as a kind of life support: it renders difficult circumstances bearable while feeding hopes of something bigger or better in the future.

Dickens's passage offers a model for describing the empathetic exchanges involved in reading. Davey transfers his 'real' life and associates into the novels: for example, he relocates the Murdstones, his step-father and step-father's sister, to the fictional world. In this new environment, he is empowered to process their cruelty. Rather than mirroring the behaviour of fictional characters, Davey benefits from the new perspectives they bring him. In addition to these transfers to the fictional world, Dickens describes the reverse, the

\footnotetext{
12 Dickens, David Copperfield, p. 54.
} 
movement of books and characters into Davey's reality. The 'glorious host' include books which have the names of their protagonists as titles, accentuating their potential for animation. Thus, rather than reporting that he read Robinson Crusoe in the little room, the adult Davey describes how someone with the name of Robinson Crusoe came to join him in the room. One further transfer is behavioural: Davey impersonates, or lives in character, for extended periods of time. As a reader, he can become anything from 'a perfect realisation' of a fictional hero to an interpretation, his 'own idea' of one. By personifying books and having them actively relate to their reader, Dickens emphasises their power to effect change and set an otherwise static life in motion.

The focus in this passage from David Copperfield is on the active processes involved in reading, and of the movements of reader, characters, and books in and out of their respective worlds. Despite this, the narrator is enigmatic about the actual mechanisms of reading, using 'read' and 'reading' only twice in the extract. For Davey, reading is equated with believing, keeping alive, replacing, relishing, impersonating, consoling, sustaining, remembering, connecting, and associating. Reading 'as if for life' can involve any of these actions, either during the process of reading, or as prolonged after-effects. It is the presence of the narrator, Davey's adult self, that emphasises the durability and continued relevance of childhood reading. By choosing to recapture these formative scenes in his autobiography, the adult narrator offers proof that reading is indeed 'for life'. His mildly ironic tone is deployed to underline the gaps in the child's understanding, and to hint at the different ways an adult, experienced in life, would be able to read or reread the very same books. Successful reading is modelled therefore not as a discrete process, but as one with potential for change and renewal. Reading 'as if for life' creates a leakage not only from one world into another, but also from one stage of life to another. 
Dickens's account of childhood reading does not only describe linear travel from one real or fictional place or time to another. Reading, for Davey is also an exercise in experiencing more than one life at the same time. This is conveyed by creating a palimpsest in terms of time and geography. When Davey reads, he superimposes an alternative map on his house and neighbourhood, overwriting the familiar landscape so that everywhere 'has an association with' or 'stands for' a location in the fictional world. The extent to which reading creates a capacious and varied geography is contrasted with his confinement to a 'region of the house' consisting of the 'little room upstairs' and Davey's bedroom. Similarly, Davey's own stultifying life and experience are obscured by a more interesting present, or by something 'beyond that place and time'.

It is interesting that Davey's library includes books originating from different European countries. Neither their provenance, nor the language in which they were read or written is mentioned, however. Their significance lies in their potential to transport a child to different places and times, and they are all experienced in the same way. While the adult narrator discerns new meanings and themes in the books that went unnoticed when he was a child, he is equally uninterested in associating the books with discrete national literatures. Dickens's template for 'reading as if for life' suggests that an English child can access the world of Gils Blas as easily as that of Robinson Crusoe. The two writers to be discussed will replicate this approach when they describe reading Dickens in Russia, and in Russian. Neither their empathy for unfamiliar subjects or enjoyment of foreign locations are impeded by linguistic or cultural barriers, any more than they are in Dickens's account of Davey's childhood reading.

Written towards the end of his life in 1910, Korolenko's short story, My First Acquaintance with Dickens, is an autobiographical account of the author's childhood in 
Zhitomir in the $1860 \mathrm{~s} .{ }^{13}$ The story can be read as an expanded version of the passage in David Copperfield already discussed: it focuses entirely on a formative reading of Dombey and Son and is structured according to a series of reading attempts, each of which increase in length, intensity, and significance. While his family circumstances were far more benign than the young Davey's, Korolenko's narrative also describes a struggle for access to books and the necessity for negotiation with his family and the urban environment in order to read them.

My First Acquaintance with Dickens starts with Korolenko looking back on what and how he read as a child. His 'first book' - the phrase with which the story begins - is identified as a novel by the 'Polish writer,' Kozhenevskii. ${ }^{14}$ As in David Copperfield, the novel is read on two levels simultaneously: from the child's point of view and according to the standards of the adult narrator, now a successful author. This narrator conveys a sense of amusement as he assesses his early reading material in terms of its suitability and 'literary tone'; he explains that his early reading choices had a 'motley, accidental and, one might say, even an opportunistic character'. ${ }^{15}$ Some of the responsibility for the subversive and piecemeal character of his early reading lay with Korolenko's family. He describes his elder brother as asserting his authority as older sibling by actively preventing him from reading novels. This brother's reading choices were determined by factors other than personal preference, he obtained books by way of a monthly subscription to a lending library run from

\footnotetext{
${ }^{13}$ This sketch is one of two that Korolenko wrote in 1910 as additional chapters to his Istoriia moego sovremennika. It was first published in Nedelia "Sovremennogo slova”, No. 199 (1912).

${ }^{14}$ It is unclear whether Korolenko read Józef Korzeniowski / Osip Vikent'evich Kozhenevskii’s works in Russian or Polish. If we consider that he was ten years old in 1863, he could have read Spekulant (1845), Kollokacja (1847), Nowe wędrówki oryginała (1850), or Garbaty (1853), novels often associated stylistically with Balzac and Dickens.

${ }^{15}$ Korolenko, V, p. 364.
} 
Butkevich's bookshop on Kievskaia Street. Books come last in the list of material goods sold by Butkevich: 'paper, pictures, notebooks, textbooks, exercise books and books for circulation by subscription'. ${ }^{16}$ The shop's circulating collection were chosen to meet demand rather than literary standards; they included 'Dumas, Eugène Sue, [Fenimore] Cooper, Rocambole, and the Mysteries of Various Palaces' ${ }^{17}$ The reader can easily infer that the cultural and pedagogical value put on reading by the adult author contrasts both with the child's indiscriminate hunger for books and the values of the literary marketplace. The circulating books are characterised as goods [tovary] which would be easily shifted [khodkie] at that time. The adjective khodki comes from the multidirectional form of the verb khodit', to go on foot; here, it refers to the books as circulating, tradeable, and popular. ${ }^{18}$ This word has multiple resonances throughout Korolenko's text; it is also a reminder of the way Davey's books and characters were constantly in motion.

The young Korolenko could only get hold of library books when his brother was out; this meant his reading process that was of necessity indiscriminate and furtive, but also fast, he reads 'at a run [beglo]'. Korolenko creates a strong impression of the child's greed for books through frequent use of verbs that refer to eating and reading, 'always on the alert, I swallowed [glotal] page after page'. ${ }^{19}$ The result of this 'opportunistic' process was that he absorbed the plots of Three Musketeers, La Reine Margot, and works by Eugène Sue in

\footnotetext{
${ }^{16}$ Ibid., p. 365.

${ }^{17}$ Ibid., p. 365. See, for example: George F. Born, Izabella, ili tainy madridskogo dvora (1870) or Evgeniia, ili tainy frantsuzkogo dvora (1871).

${ }^{18}$ Ibid., p. 365. The children's writer Kornei Chukovskii, wrote that his books benefited from 'enormous success' and were the 'most popular [samye khodkie] books in Russia.' K. Chukovskii to I. Repin, $2^{\text {nd }}$ February 1924, in Il'ia Repin, Kornei Chukovskii, Perepiska (1906-1929) (Moscow: NLO, 2006).

${ }^{19}$ Korolenko, V, p. 369.
} 
fragments. ${ }^{20}$ His perception of the books was therefore impressionistic and incomplete: 'a landscape beneath a swirling fog', with images that 'appeared and disappeared, scared away by my brother's footsteps'. ${ }^{21}$ As a result, the plot-driven classics of French literature are received by the child as a single composite novel with moving and interchangeable parts. At this stage of his reading life, we have the impression that Korolenko is tormented by his hunger for books, and by the impossibility of putting their different parts together.

Korolenko's elder brother inadvertently creates the conditions whereby the reader himself must circulate in order to gain access to circulating books; he allows Korolenko to return his library books to Butkevich's shop. The child's opportunity to read circulating (khodkie) books while himself moving around the city on foot (khodki), adds complexity to existing associations of reading with movement. The reading process acquires a spatial dimension and the child begins to traverse the city: 'The library was far away from our home, so the book was at my disposal across the whole space. I began to read on foot (na khodu) $\ldots{ }^{22}$ The idiom used to describe his first reading of Kozhenevskii, 'at a run' (beglo) is now literalized: the boy moves through the urban landscape while simultaneously engaged in a 'headlong run through the pages (stremitel'nyi beg)'. He encounters further obstacles: 'At first I was unable to adapt properly to the motion of the street and risked falling under a carriage or bumping into passers-by'. ${ }^{23}$ Having learned to 'run' through books as their reader, he now has to learn to read the city and its rhythms as a multi-tasking pedestrian. The city throws social restrictions and actual hazards in his way, making reading all the more valuable through its vulnerability to interruption. The boy's reading journeys are time limited: he

\footnotetext{
${ }^{20}$ The Three Musketeers first appeared in Russian translation in 1846; Queen Margot in 1845.

${ }^{21}$ Korolenko, V, p. 365.

${ }^{22}$ Ibid., p. 365 .

${ }^{23}$ Ibid., p. 366.
} 
describes having to skip to the endings in order to return books on time: 'Knights, robbers, defenders of innocence, beautiful ladies - all in some kind of whirlwind, rushing around in my head under the din of street traffic only to break off disjointedly, strangely, puzzlingly, teasingly, in my heated but unsatisfied imagination'. ${ }^{24}$ While this account is amusing, the adult narrator suggests that this mode of reading brought the boy significant but undefined intellectual harm. This account of reading circulating books, khodkie knigi, on foot ( $n a$ $k h o d u)$, in a city that is itself in constant motion, is used to contrast with the more focused reading of Dickens that follows.

The story's title gives away the end point of this sequence of problematic reading situations: the plot is advancing towards the boy's transformational reading of an unnamed novel by Dickens. The child's movement towards his own cultural and emotional maturity is narrated in terms of a quest to be able to appreciate Dickens. In its first stage, a novel in the form of a journal supplement provides the walking child reader with yet one more compromised attempt to read for plot. ${ }^{25}$ Here, Korolenko's readers have the opportunity to experience the patchwork reading process for themselves. Rather than giving a summative description of genres and grouped titles as before, the narrator employs the child's naïve voice to quote phrases and names from the novel. This takes up a larger proportion of text than the previous readings, slowing down Korolenko's personal narrative; it also replicates the child's incremental process of absorbing the book. According to the child, the novel involves 'some sort of tall, stern, unpleasant man' who is in charge of an institution in London. As the details of the novel accumulate, Korolenko's reader can share the narrator's

\footnotetext{
${ }^{24}$ Ibid., p. 366.

${ }^{25}$ As a child, Korolenko could have read one of two Russian translations of Dombey and Son: both Vvedenskii's translation in Sovremennik and A. I. Butakov's in Otechestvennye zapiski appeared in instalments between 1847 and 1848, the first English serial publication occurred between October, 1846 and April, 1848.
} 
double perspective. While we read along with the child, who rejects the book as 'a woeful and uninteresting adventure to which I reacted with scorn', we are also likely to recognize Dombey and Son. On observing his brother's more positive reception of the book characterized by loud guffaws - the child is challenged to try again. This second attempt sees Korolenko applying the language of walking (rather than running) to his reading: 'I wandered, gropingly through the book, colliding - literally on the street - with a whole procession of characters' ${ }^{26}$ It is notable that, as the child slows down to engage better with his reading, it becomes increasingly difficult for Korolenko's reader to distinguish between his two actions, walking and reading. Reading a book is described as a walk with obstacles, just as walking through the streets of Zhitomir has its own obstacles. These obstacles are often people: the 'whole procession of characters' is reminiscent of Davey's 'glorious host'. The ambiguity as to which characters are real and which are fictional is a matter of indifference to the child, who, in this account, can be immersed in the life of the city and the book simultaneously.

As Korolenko progresses through the book, we are further exposed to the process of reading without plot. Visual snapshots of characters alternate with snatches of names and voices: 'In front of me flickered (promel'knula) the figure of little Paul and his sister Florence'. The child misunderstands the idiomatic nature of 'they were accustomed to dealing in hides but had never had any dealings with women's hearts', assuming that one character is 'a merchant, trading in hides' ${ }^{27}$ His partial comprehension is also conveyed by

\footnotetext{
${ }^{26}$ Ibid., p. 366.

${ }^{27}$ Ibid., p. 366. The quotation from Dombey and Son in My First Acquaintance with Dickens is likely to be an approximation; it does not appear in any of the translations available in 1912. The line is more succinct in English: 'Dombey and Son had often dealt in hides, but never in hearts.' Charles Dickens, Dombey and Son (London: JM Dent, 1997), p. 4.
} 
approximations of Dickensian names: 'Uncle Smol' [Sol], Captain Tuddle [Cuttle] and his iron hook instead of a hand... No, still not interesting... Toots and his love for waistcoats... a fool... what did it have to do with me?' ${ }^{28}$ Ellipses convey the disjointed nature of his reading; they also indicate switches between retellings from the text and the reader's dismissive evaluations. At this stage in Korolenko's text the child's experience of reading Dickens still resembles the impressionistic amalgamation of French novels: its characters are unanchored to any coherent plot.

The catalyst that converts this inferior experience into one of comprehension and empathy is the image of Florence standing motionless on the threshold of her father's study. Both Florence and Korolenko come to a halt, the latter for the first time in the reading process. This is the moment when the young Korolenko becomes able to appreciate a coherent fictional world: 'All at once, like lightning, a picture of all the fragments that had flickered so impassively across the surface of my reading lit up. I regretted that I had lost so much time... Now I decided to make use of what time was left: I read greedily for another two hours' ${ }^{29}$ Korolenko also shows how he gained empathy for the author's decisions, and appreciation for his 'belief' and the accuracy of his portrayal:

Surely he [Dickens] could have written it differently... But no. I felt that he couldn't have done, that this was exactly the way it was, and that he only had to observe the horror for him to be as shaken as I now was... And thus, with the fading scream of the poor lonely girl, was the disillusionment, pain and passion of his own heart united... And I repeated after him, with hatred and a thirst for revenge: yes, yes, yes! He will remember this, certainly; he will certainly remember this in the years to come. ${ }^{30}$

\footnotetext{
${ }^{28}$ Ibid., p. 366.

${ }^{29}$ Ibid., p. 369

${ }^{30}$ Ibid., p. 369.
} 
References to 'he' throughout this passage are to Dickens, although he and his novel are still unidentified. However, the distinction between Dickens and his reader in Zhitomir becomes increasingly unclear. Korolenko's first-person narrative moves from quoting Dickens, to repeating his words 'after him,' to writing as Dickens, using language that increasingly resembles what he is reading in terms of rhetoric and lexicon. Korolenko conveys the child's new ability to become involved in the world of the novel by making it increasingly difficult for his reader to distinguish the child's speech from that of Dickens; similarly, Dickens's characters' affective responses become inextricable from those of Korolenko. A further device demonstrating the child's integration in the novel's present involves using a kind of free indirect speech on behalf of the characters: 'the girl stood in the doorway. To go in or not to go in?'. ${ }^{31}$ This technique, whereby the reader shares suspense along with the characters, alternates with the adult narrator's more distanced and retrospective stance, which nonetheless conveys the emotional investment he experienced as a child: 'I at once felt alertly the death of the unknown boy, and that night and that grief of loneliness and gloom, and, and.... 32

Korolenko has a final opportunity to read Dombey and Son when he is charged with returning his brother's copy to the bookshop. With his destination in sight, he finds a ledge between a church and its neighbouring building and perches there to read, while a curious crowd gathers to watch him. This is a symbolic location: the child reader exists somewhere in between present-day Zhitomir and Dickens's London. However, like Davey, he is also in both places at once, living his book and family obligations at the same time. Korolenko returns to reading on foot in the last sentence of his account: 'So there it is, how I first - one

\footnotetext{
${ }^{31}$ Ibid., p. 367.

${ }^{32}$ Ibid., p. 367.
} 
might say, on foot [na khodu] - became acquainted with Dickens' ${ }^{33}$ The ambiguity of this final sentence conveys the child's position, occupying reality and imagination at the same time. It can be interpreted as meaning that Korolenko became acquainted with Charles Dickens in person one day while walking through Zhitomir, or equally, that he read a novel by Dickens for the first time while walking in the streets of Zhitomir. Korolenko's account shares an emphasis on the dynamism of reading with the 'reading as if for life' passage from David Copperfield; it also takes it further, literalising the reader's empathetic and imaginative movement by having him walk and read at the same time.

In My Passion for Dickens by Nelli Morozova (1990), the life journey of a reading child starts, coincidentally, at the point Korolenko ends his account, at around the age of ten. ${ }^{34}$ Accordingly, Morozova represents herself as a mature reader with full comprehension and engagement from the outset. Her first acquaintance with Dickens involved reading Great Expectations in Russian in the early 1930s, while her family was still part of the artistic and literary elite in Taganrog. ${ }^{35}$ She and Korolenko had a mode of reading in common:

At the time, I had been entrusted with a book by Dickens, Great Expectations. I was making my way to Sonia's home, all the while transfixed (ustavias') by the book I held open in front of me. I was constantly being scolded for my manner of reading on foot. $^{36}$

\footnotetext{
${ }^{33}$ Ibid., p. 372.

${ }^{34}$ Morozova does not refer to Korolenko’s My First Acquaintance with Dickens in her autobiography.

35 The Russian edition of Great Expectations most likely to have been read by Morozova used a translation from 1893: Bol'shie ozhidaniia, transl. by M. Shismareva (Moscow-Leningrad: Gosizdat, 1929). Subsequent editions of the same translation came out in 1930, 1933, and 1935.

${ }^{36}$ Morozova, p. 70.
} 
In Morozova's account, reading is once again associated with movement; it reveals a familiar contrast between the limited space inhabited by the child reader and her opportunities for 'travel' to 'a different time and place' through reading. Whereas Davey's circumstances resulted in the creation of extensive imagined geographies from his bedroom, Korolenko and Morozova had limited freedom to explore their respective urban environments. However, they give similar emphasis to the restrictions that governed their freedom of movement as children. Morozova's description of being 'transfixed' or 'mesmerised' by Great Expectations could refer to either Davey or Korolenko's relationship to their reading. Morozova is so fully immersed in her book that she is unaware of any surrounding distractions and Great Expectations overwrites her own experience:

Sonia's home was as good as mine, but even if I had fallen into completely unknown surroundings I wouldn't have noticed. 'Can you tell me what you just ate?' asked Sonia at the dinner table, where the open book was lying in front of me. 'Pork pie,' I answered distractedly as little Pip had only just appropriated this item from his shrewish sister for the convict. ${ }^{37}$

Morozova describes her distraction from real life and ability to be 'transfixed' by Dickens with the benevolent amusement familiar from the adult narrators in My First Acquaintance with Dickens and David Copperfield.

Subsequent readings of Dickens show Morozova exchanging her own reality for fictional environments with more deliberation: she describes making conscious choices to

\footnotetext{
${ }^{37}$ Ibid., p. 70. The Russian translation cited by Morozova in My Passion for Dickens is not the one she would have read as a child (see Note 33). By the 1970s, a nativizing Soviet translation was available: Bol'shie nadezhdy, transl. by M. Lorie, Sobranie sochinenii v 30 tomakh (Moscow: Goslitizdat, 1957), xxiii, p. 20. This translation has Pip stealing svinoi pashtet or a pork 'meat paste' for the convict, although Morozova reverts to the pork pie in her quotation.
} 
'keep her fancy alive' through reading. This was not only a way to feed her imagination but an important coping strategy, a way to escape from emotional and physical privation. After her father's arrest in 1936, Morozova was sent to live with her grandmother in Ufa; here, Bleak House furnished her with role models in the character of Esther, and less obviously, in Lady Deadlock: 'I responded keenly to Esther's solitude. [...] I understood Lady Deadlock all too well, her need to maintain a haughty and chilly exterior while on the inside she was consumed with fear that her shameful secret would be revealed to the world' ${ }^{38}$ In addition to responding 'keenly,' Morozova understands and identifies with the inner world and dilemmas of the characters rather than sympathising from a distance. ${ }^{39}$ After her father's sentencing in 1937, Morozova was exiled with her mother to a rural village in Bashkortostan. Here, her restricted intellectual and physical life resulted in Morozova choosing to inhabit alternative environments even without the support of the characters with whom she empathised:

I found myself in the bright, cosy kitchen at Manor Farm in Dingley Dell, drinking from the common cup, and listening to Christmas mystery stories; or I would be tearing along in a post chaise with the other passengers, my pleasantly warm grog in my hands. ${ }^{40}$

These imaginative journeys, unlike Morozova's freezing walks to sell her possessions in the market or to procure food and firewood, are characterised as effortless and instantaneous. Reading permits her to 'find herself in' or be 'surrounded by' fictional environments which successfully replace, for example, the draughty hut she shares with a local Tatar family. Furthermore, reading and its ability to transport her elsewhere are presented as a ritual that she can both initiate and repeat:

\footnotetext{
${ }^{38}$ Ibid., p. 153.

${ }^{39}$ See Keen, p. 4.

${ }^{40}$ Morozova, p. 188.
} 
It became more real than the wolves out the window and the mournful light produced by the kindling. I would leaf through the phrases I knew so well, not hurrying, and with judicious economy, and I'd start to be surrounded by those good, happy, eccentric people. ${ }^{41}$

This passage offers one more example of the type of two-way movement previously outlined in relation to Dickens's description of the young Davey's 'travels'. While Morozova can 'travel' to Dingley Dell, reading also can also populate her immediate environment with Dickens's attractive characters.

As a book-length autobiography, Morozova's text offers more opportunities than Korolenko's for establishing Dickens as a lifelong resource. Her narrative allows for repeated entries of the novels into her life, multiplying the effect of the distanced perspective taken by Korolenko's adult narrator. Readings function as defining moments in Morozova's biography even at the expense of positive life events. For example, when her father was commissioned by Bukharin to organize the Chekhov jubilee, ten-year-old Morozova's discovery of Pickwick Papers provided a high point of equal significance: 'the summit of my parent's 'prosperity' fell in the summer of 1935 , but the peak of my happiness that year had a name that was almost a trademark: The Pickwick Club'. ${ }^{42}$ Pickwick accompanied Morozova to university in Alma-Ata, and then through film school and her career as a screen-writer. He also has the last word in her autobiography: his account of Sam, who 'got himself arrested in order to remain at my side', forms the entire final paragraph of the book. ${ }^{43}$

As the autobiography progresses, reading Dickens becomes an increasingly effective method by which the child can reframe and neutralize difficult experiences in the moment.

\footnotetext{
${ }^{41}$ Ibid., p. 188.

${ }^{42}$ Ibid., p. 107.

${ }^{43}$ Ibid., p. 256.
} 
When attacked by a group of children hurling coal, she is rescued by someone throwing a watermelon at her attackers. Comfort is derived not from narrating the incident to her mother, to whom she reports having accidently fallen in a ditch, but by rereading a relevant scene from Pickwick Papers: 'I knew where to find consolation, I immediately opened it to the necessary page'. ${ }^{44}$ She is referring to Pickwick in the prison cell, fighting back when his nightcap is snatched away; it combines both bravado and slapstick, and ends in reconciliation and laughter. Morozova maps the episode on to her own experience in such a way as to disempower her adversaries, physically and intellectually: 'Whereas Mister Pickwick's offender danced insolently under his nose in the prison cell; mine hid in the bushes like cowards' ${ }^{45}$ She remembers her 'high-minded saviour' as Pickwick's equal and the association with the fictional scene has apparently overwritten her memory of the event. The mechanism by which she reads her own world through Dickens's novels operates to such a degree that the traumatic memory of her persecution is almost completely suppressed. She claims that hearing a watermelon being cracked open reminds her of Pickwick and his nightcap - rather than the experience of being set upon by other children - 'to this day'. This extreme form of rewriting her own experience is evidently the result of practice: her solitary life in Ufa with her grandma, is so 'stultifying' that she retells the plot of Bleak House in letters to her mother in place of describing events in her own life. ${ }^{46}$

\footnotetext{
${ }^{44}$ Ibid., p. 180.

${ }^{45}$ Ibid., p. 181. Morozova quotes from Dickens, Posmertnye zapiski Pikvikskogo kluba, transl. by Krivtsova, Lann, in Sobranie sochinenii v 30 tomakh (Moscow: Goslitizdat, 1957), iii, p. 245-6. In English: 'This foolish fellow,' said Mr. Pickwick, tapping Sam on the head as he knelt down to button up his master's gaiters — 'this foolish fellow has got himself arrested, in order to be near me.' Dickens, The Pickwick Papers (London,
} Nonesuch Press: 1937), p. 620.

${ }^{46}$ Morozova, p. 150. 
Dickens offers Morozova something more than a series of safe, cosy spaces to escape to, and her claims for her reliance on books far surpasses those of Korolenko, Davey, or Dickens. In the incident with the watermelon, and in many others in the memoir, solace and guidance are derived from Dickens in place of her family members. From the moment of her father's arrest, Dickens increasingly replaces both of Morozova's parents in the autobiography as a source of reassurance and authority. Of course, the few physical copies of his works she carried from place to place also replaced her parents for much of her childhood. While the examples presented so far are individual, Morozova also offers her readings of Dickens as proof that the effects of empathetic relationships formed by reading can extend beyond individual behaviour. She argues that his novels offered a workable alternative to the values inculcated by Soviet institutions, that they functioned as a dependable resource by which children like her could evaluate both their own behaviour and the morality of others:

Out of the murkiness of a dismal childhood, Dickens led towards a place of warmth and light. One could not spend time there without it having an effect. A sense of justice could be discovered thanks to these Englishmen, and Russian children, spiritually orphaned, were warmed by the moral protection of their great compatriot. ${ }^{47}$ Morozova describes multiple instances of adults betraying each other to the authorities or choosing to privilege party ideology over human decency. In one example, she recalls the anguish that followed the telling of an incautious story to a school friend. She accounts for her impulse to atone in the following way: 'what happened afterwards would never have happened without counterweights, the example set by my parents and by Dickens, that I can say with certainty'. ${ }^{48}$ In other situations, Dickens's characters supersede her parents' examples. Morozova's mother attempted to counter her school teacher's lessons about heroic

\footnotetext{
${ }^{47}$ Ibid., p. 91.

${ }^{48}$ Ibid., p. 92.
} 
children who reported on their parents by entreating her to imagine betraying her own family members. Morozova writes that she immediately found a better example in Dickens and reframes the question as 'Could Pip have betrayed Estella?'. ${ }^{49}$

Morozova also cites Dickens's plots as an important source of security. Where Davey enjoys reading open-ended, picaresque plots, Morozova prefers predictability and a guaranteed conclusion. She generalises from a reading of Bleak House to argue that in Dickens 'villainy is always exposed and evil self-combusts' ${ }^{50}$ Korolenko's older brother makes a similar point: 'Dickens always ends with the good people triumphing and reconciling' ${ }^{51}$ Unlike Dickens's first English and Russian readers who read the novels in instalments, Morozova and Korolenko could be certain that the novel's ending was within reach, and with it, the plot's neat resolution. Clearly, Morozova's insistence on the novels being both morally consistent and finite stems from the contrast to her own experience. Unlike in Great Expectations, where the secret of Pip's fortune is revealed at the end, Morozova was habituated to receiving far less information about the important characters in her own life. The chapter in which she describes her absorbsion in Great Expectations also includes the story of her grandfather's life and death: his fervent belief in the Revolution, his disillusionment and participation in the Worker's Opposition faction, his removal from Moscow to Ufa, and the threat of arrest during his final illness requiring him to be 'on the run' ${ }^{52}$ While the adult narrator is in possession of her grandfather's complete biography, she recreates her former ignorance of the reasons for his sudden appearance and disappearance from their rooms in Taganrog: 'there wasn't really anything astonishing about this. If a

\footnotetext{
${ }^{49}$ Ibid., p. 90.

${ }^{50}$ Ibid., p. 91.

${ }^{51}$ Ibid., p. 372.

52 Ibid., p. 71.
} 
person can appear, like the snow that falls on your head, he can disappear in much the same way. ${ }^{53}$ Months pass before she finds out that her grandfather has died, and decades pass before she can engage with the moral complexity of his party allegiances.

I have argued that Dickens's novels are valuable to Morozova for the alternative lives and environments they open up. In My Passion for Dickens, however, the similarities in the circumstances of Morozova and Dickens's child characters are also demonstrated. These correspondences are rarely explicit or voiced by the narrator. Instead, they are constructed by the integration of quotations from Dickens, and by the use of common themes. In the chapter just discussed, Morozova and Pip from Great Expectations are linked through descriptions of eating bread. The description of how Morozova's grandfather brings the first white bread she has ever tasted, 'we were amazed by its texture and nibbled away at tiny little pieces with relish', is followed by a quotation from Great Expectations in which the convict shakes Pip until he finds the piece of bread in his pocket. These two experiences appear in a single paragraph, but no explicit comparison is made. It is up to Morozova's reader to discern that the bread is equally precious in both instances, but that while Pip supplies the convict, it is the convict, Morozova's grandfather, who brings the bread to his granddaughter. ${ }^{54}$ The unavailability of white bread and memories of starving neighbours in Taganrog, her peripatetic existence and ever-present threat of losing both parents, all point to similarities between Morozova's childhood and those of Dickens's child characters. The contrast between her account of growing up in the 1930s and the proscribed Soviet narrative of happy

\footnotetext{
${ }^{53}$ Ibid., p. 72.

${ }^{54}$ Ibid., p. 80. Morozova suggests that his former association with the Workers' Opposition faction put him in danger in the 1930s.
} 
childhood is stark. ${ }^{55}$ Morozova's early experience that a Soviet citizen's life was less likely to turn out well than that of a character in a novel by Dickens was also provocative. By demonstrating that the 'hungry reader' was more than a metaphor, Morozova's account counters a commonplace in Western criticism which holds Russian interest in Dickens to be 'synthetic, for it could never have been developed and maintained without the active encouragement of the government, which probably sees in Dickens's treatment of social problems a useful propaganda weapon' ${ }^{56}$ Instead, Dickens was enlisted by Morozova to help her reveal the inadequacy and immorality of the Soviet regime.

In contrast, Korolenko's My First Acquaintance with Dickens would have been accommodated more easily by official Soviet narratives. ${ }^{57}$ The story offers evidence that even a relatively privileged child had difficulty in obtaining good books in the 1860 s; it shows how business interests determined what was available for children to read, while demonstrating the importance and transformative nature of reading. ${ }^{58}$ When Korolenko's readers identified something 'Dickensian' in his prose, they were referring to stylistic similarities and creative

\footnotetext{
55 'From the mid-1930s, the mainstream Soviet press generally reported stories about the ill-treatment of children only if they involved cases from benighted Western countries [...] or if they portrayed the dreadful lives led by children in Russia before 1917.' Catriona Kelly, Children's World (Newhaven, London: Yale University Press, 2007) p. 111.

${ }^{56}$ K. Harper, (Dec., 1953), 'Russian Translations of Nineteenth-Century English Fiction', Nineteenth-Century Fiction, 8: 3, pp. 188-197. p. 188.

${ }^{57}$ See Note 55 .

${ }^{58}$ See 'A child does not read books. He nourishes the tender roots of his soul with them.' And 'The children book, as an important weapon of education, must be disseminated as widely as possible.' L. Kormchii, 'Zabytoe oruzhie [A forgotten weapon]', Pravda 1 $7^{\text {th }}$ February 1918/ No. 28 p.3. Detskaia literature 1967, 7, pp. 18-19.
} Morozova makes a similar point: 'At that time there were no books in the shops', Morozova, p. 81. 
choices in common rather than a shared ideology between the two writers. ${ }^{59}$ 'My First Acquaintance with Dickens' does indeed read as a kind of 'Dickensian' composite. As the young Korolenko walks through his city, absorbed in Dombey and Son, he becomes an object of attention to a crowd of 'young Jews - a lively, adroit and mischievous people, who threw out ironic comments and asked something or other intrusive'. ${ }^{60}$ It is as if the London of the novels is reproduced around him in 1860s Zhitomir: the Jewish street gangs are familiar from Oliver Twist; Korolenko's hiding place in the churchyard niche recreates the scene where the solitary Davey reads and the 'other boys' play in the churchyard; and, in Dombey and Son, gangs of children torment Biler in his new school uniform, causing Florence Dombey to get lost in the fray. Korolenko's childhood experiences are aligned with those of Dickens and Davey; he reproduces the latter's experience of reading as a way to create an alternative geography. Korolenko suggests both that Zhitomir is a location that might have interested Dickens and that it assisted in his formation as a writer with similar sensibilities to Dickens. While Korolenko and Morozova's accounts of their imaginative ability to relate to Dickens are convincing, a reader of Dickens in English is still likely to find their interactions to be somewhat incongruous. It seems unlikely that Dingley Dell or Pickwick could be comforting to a child in 1930 's Siberia, or that 1860 s Zhitomir could be re-imagined as an English country churchyard. In concluding, I will suggest that translation facilitated this closeness, both at the time the children read Dickens, and in their autobiographical accounts of these readings.

\footnotetext{
59 'One can hear Dickensian intonation and motifs in Korolenko's stories about children', I. Katarskii, Dikkens v Rossii (Moscow: Nauka, 1966), p. 307; 'With Dickensian warmth, but without his true bourgeois sentimentality, [...] Korolenko [...]', Roza Luxemburg (1919) in Korolenko, Sobranie sochinenii v 6 tomakh (Moscow: Gosudarstvennoe izdatel'stvo khudozhestvennoi literatury, 1954), I.

${ }^{60}$ Korolenko, V, p. 371.
} 
In both My First Acquaintance with Dickens and My Passion for Dickens, quotations from Dickens appear in the same language and alphabet as Korolenko and Morozova's own prose. The only words 'foreign' to Russian are proper names transliterated into the Cyrillic alphabet, for example: Dzho, Talkingkhorn, Marshal'si. Of equal importance is the fact that the distinctions Dickens made between different characters' accents and grammatical usage are largely absent in Russian translation. For example, Dickens represents Joe Gargery’s speech in Great Expectations as follows:

'There's one thing you may be sure of, Pip,' said Joe, after some rumination, 'namely, that lies is lies. Howsever they come, they didn't ought to come, and they come from the father of lies, and work round to the same. ${ }^{91}$

A re-translation into English from the Russian translation of Great Expectations quoted by Morozova in My Passion for Dickens shows Joe's speech to be undistinguished from that of Pip, or the narrator:

'There is one thing that you should never doubt, Pip,' he said, thinking it through a little, 'A lie is a lie. Where ever it comes from, it's just as bad, because it comes from the father of lies and will lead right back to him. ${ }^{62}$

While Morozova, Dickens, Pip, and Joe Gargery can be observed to share a language and register, there are characters in My Passion For Dickens whose language is differentiated considerably. Morozova differentiates her Tatar neighbours' Russian from her own by representing their speech phonetically. Not only do they shout 'Trotskyite $-000-000-$ enemy - Trots-ky-ite', at Morozova, they ask her 'Don't you understand Russian?', and call her a 'foreigner'. ${ }^{63}$ Their lack of verbal acuity reinforces her cultural superiority, augmented

\footnotetext{
${ }^{61}$ Dickens, Great Expectations (London, Nonesuch Press: 1937), p. 66.

${ }^{62}$ Morozova, p. 71.

${ }^{63}$ In Russian: 'Trotskistka - u u vrazhina - Trots-kis-tka!', Morozova, p. 154; 'Ty sho, russkogo iazyka ne
} 
by her ability to employ ironic epithets from Dickens as in the description of her defender in the watermelon-throwing incident. Morozova has more in common with the language of Dickens in Russian translation than that spoken by her neighbours. A similar phenomenon can be observed in Korolenko's story where non-Russian words are not from Dombey and Son but the speech of the local Jewish children.$^{64}$ In Russian translation, Dickens's characters are both native and familiar; they speak the Russian of the intelligentsia, the language of their translators. Furthermore, the fact that Dickens's novels were retranslated multiple times in the lives of both Korolenko and Morozova means that his language was repeatedly modernised and brought into closer proximity with that of his Russian readers. For example, Morozova's quotations from Dickens come from translation of the novels published in the 1950s and 60s rather than those she could have read as a child. This fascinating effect, unavailable to readers of the English original, meant that language of the novels would have updated more than once in her reading life, that Dickens's contemporaneity was renewed.

The linguistic proximity between the Dickens and his Russian-language readers explains why Morozova was able to describe Dickens both as 'English' and as her 'compatriot'. However, neither Korolenko nor Morozova ever mention reading Dickens in translation. In contrast to their complex narrative representations of reading and focus on the duration and mobility of their interactions with books, they do not acknowledge that the books themselves have travelled out of their original language, or circulated far from their original place of publication. One could conclude that these Russian readers were invested in proving that the geographical, temporal, linguistic, and cultural distances between their lives, and those of Dickens and his characters, was irrelevant. I have argued elsewhere that this is a

ponimaesh?', ibid., p. 181.

${ }^{64}$ Korolenko, V, p. 370. Korolenko's brother points out that the Jewish children in the streets are calling him 'meshiginer'. 
common feature of Dickens's reception in Russian literature; ${ }^{65}$ the work of Korolenko and Morozova should be seen in the context of Dostoevskii's comments on Dickens from 1873. Russian writers have frequently made extreme claims for their receptiveness to English literature, but none are as confident as Dostoevskii's argument for the Russian love of Dickens:

We, after all, understand Dickens in the Russian language, I am certain, almost exactly as the English do, even, perhaps, with all its subtleties; we even, perhaps, love him no less than his compatriots do. And yet how typical, distinctive, and national Dickens is. What then must one conclude? Is this understanding of other nations a special gift that Russians possess to a higher degree than other Europeans? ${ }^{66}$ Just twenty years after the first translations appeared in Russian, Dostoevskii argued for an 'almost exact' match between English and Russian readers' reception of Dickens. In Russia, he states, love and understanding are unimpeded by the English writer's 'typical, distinctive, and national' qualities, indeed, the Russian reader is uniquely equipped to understand him. My reading of two Russian autobiographical accounts of empathetic and rewarding encounters with Dickens's novels, is not intended to prove that Dostoevskii is correct, or that their authors have similarly polemic aims in writing them. However, the three Russian authors all erase transnational processes such as translation to a similar extent, perhaps implying that transmission occurred through the 'love and understanding' identified by Dostoevskii. Curiously, demonstrating an affinity to Dickens seems to have been a way to

\footnotetext{
${ }^{65}$ E. Finer, 'Dickens in Russia: The Soviet Period', in The Reception of Dickens in Europe, ed. M. Hollington, Reception of British and Irish Authors in Europe, Series ed. E. Shaffer, 2 vols (London: Bloomsbury, 2013), I, pp. $103-120$.

${ }^{66}$ F. M. Dostoevskii, F. M., 'IX - Po povodu vystavki' in Dnevnik pisatelei (1873), Sobranie sochinenii v 15 tomakh (Leningrad: Nauka, 1988-1996), xii.
} 
prove oneself as a Russian reader with cultural capital, and, subsequently, as a Russian writer worthy of attention. While Dickens's value lay, variously, in his provision of a reliable, plotted world, or in his ability to nurture empathetic readers, he could also convert children who read him into future Russian writers. As if to perpetuate the cycle, Morozova's readers and critics describe reading her autobiography in similar ways to her account of reading Dickens. In a review of My Passion for Dickens, Alexandr Zorin employs a hyperbolic style apparently in imitation of both Morozova and Dickens: not only does he offer his own matching account of Dickens's function as a moral compass for Soviet citizens, he employs a further iteration of the walking and reading metaphor to describe the reader's journey through life. ${ }^{67}$ Finally, entries on Livejournal accounts suggest that a new generation of Russian readers may be reading Morozova 'as if for life'. ${ }^{68}$

By the time Morozova wrote her autobiography in the 1980s, the assimilation of Dickens into the Russian canon was so complete that there was little need to account for the fact that he was neither a compatriot or a contemporary. Indeed, he was felt to be both these things. In conclusion, I suggest that the ability of the Russian Dickens to detach from his context and assimilate within new ones is enviable. Without the advantage of re-translation, Dickens or Pickwick are much less likely to be experienced by English readers as contemporaries. In contrast to their film, TV, and stage versions, the novels are more likely to be experienced as 'unrelatable' texts one was forced to read at school, even as the instrument

\footnotetext{
67 A person with clear points of orientation (Dickens being one of them) was capable of picking out particles of truth from an ocean of lies, of gaining hope at the edges of disillusionment, of finding a way out of a dead end'. A. Zorin, 'Nelli Morozova. Moe pristrastie k Dikkensu', Znamia 4 (Moscow, 2012).

68 'Nelli from My Passion for Dickens is a bookish girl just like us, Katia )))', 'I'm going to keep her book on the shelf by my bed'<http://iamaglika.livejournal.com/31897.html $>$ and

<http://iamaglika.livejournal.com/41816.html> [accessed 5 March 2017].
} 
of the ultimate punishment in $A$ Handful of Dust. ${ }^{69}$ Perhaps Russian literary interactions with Dickens could cause the English reader to reread him 'as if for life' or see his characters as ‘just like us' once again?

I am grateful to Claire Whitehead, Emily Lygo and the anonymous readers of this article for their useful feedback; this project also benefited from support from the University of St Andrews and the Santander Research and Travel Fund.

\section{Works Cited:}

Annenskaia, A. N., Ch. Dikkens ego zhizni i literaturnaia deiatel'nost' (St Petersburg: Iu. N. Erlikh, 1892).

Apostolov, N. N., 'Tolstoi i Dikkens', in Tolstoi i o Tolstom: Novye materialy (Moscow: Tolstovskii muzei, 1924), pp. 104-123.

Brodskii, J., 'Nobel Lecture', 8 December, 1987', http://www.nobelprize.org/nobel prizes/literature/laureates/1987/brodsky-lecture.html [accessed: 1 November, 2016].

${ }^{69}$ Reading 'as if for life' acquires a more sinister meaning in Evelyn Waugh's A Handful of Dust (1934) where the protagonist is stranded in the jungle and forced to read the complete works of Dickens aloud to his companion, for the rest of his life. 
Buckton, O., 'The Reader Whom I Love': Homoerotic Secrets in 'David Copperfield.' ELH, vol. 64, no. 1, 1997, pp. 189-222.

Chukovskii, K., Il'ia Repin, Kornei Chukovskii, Perepiska (1906-1929) (Moscow: NLO, 2006).

Dickens, C., Bol'shiia nadezhdy in Otechestvennye zapiski (1861), I.

-- Bol'shie nadezhdy, transl. by M. Lorie, Sobranie sochinenii v 30 tomakh (Moscow:

Goslitizdat, 1957), xxiii.

-- Bol'shie ozhidaniia, transl. by M. Shismareva (Moscow-Leningrad: Gosizdat, 1929).

-- David Copperfield (London: Nonesuch Press, 1937).

-- 'David Kopperfil'd-mladshii iz doma Grachi, chto v Blonderstone. Ego lichnaia istoriia', transl. I. Vvedenskii, in Otechestvennye zapiski, 1-9 (1851).

-- Dombey and Son (London: JM Dent, 1997).

-- Great Expectations (London, Nonesuch Press: 1937).

-- The Pickwick Papers (London, Nonesuch Press: 1937).

-- Posmertnye zapiski Pikvikskogo kluba, transl. by Krivtsova, Lann, in Sobranie sochinenii v 30 tomakh (Moscow: Goslitizdat, 1957), iii.

--'Prikliucheniia, opyty i nabliudeniia Davida-Kopperfil'da-mladshego', transl. Nikolaev, Tsimmer, Butuzov, in Sovremennik, 1-9 (1851).

-- Zhizn’ Devida Kopperfilda, rasskazannaia im samim, transl. by A. V Krivtsova, E. Lann (Moscow: Gosudarstvennoe izdatel'stvo khudozhestvennoi literatury, 1954).

-- 'Zhizn', prikliucheniia, opyty i nabliudeniia Davida Kopperfil'da, soch. Karla Dikkensa', transl. Miller, Kaloshin, in Moskvitianin, IV (1849), 'Inostrannaia slovesnost'”, pp. 1-40, 45102. 
Dostoevskii, F. M., 'IX - Po povodu vystavki' in Dnevnik pisatelei (1873), Sobranie sochinenii v 15 tomakh (Leningrad: Nauka, 1988-1996), xii.

Finer, E., 'Dickens in Russia: The Soviet Period', in The Reception of Dickens in Europe, ed. M. Hollington, Reception of British and Irish Authors in Europe, Series ed. E. Shaffer, 2 vols (London: Bloomsbury, 2013), I, pp. 103-120.

Fridlender, Iu., Katarskii,, I., Charl'z Dikkens Bibliografiia russkikh perevodov i kriticheskoi literatury na russkom iazyke 1838-1960. (Moscow: Izdatel'stvo vsesoiuznoi knizhnoi palaty, 1962)

Gagarin, Y. Doroga v kosmos (Moscow: Voennogo izdatel'stva Ministserstva oborony Soiuza SSR, 1961).

Gorky, M., 'V liudiakh' in Sobranie sochinenii v 30 tomakh (Moscow: Gosudarstvennoe izdatel'stvo khudozhestvennoi literatury, 1951), XIII.

Harper, K. (Dec., 1953), 'Russian Translations of Nineteenth-Century English Fiction', Nineteenth-Century Fiction, 8: 3, pp. 188-197.

Keen, S., Empathy and the Novel (Oxford: Oxford University Press, 2007).

Kelly, C., Children's World (Newhaven, London: Yale University Press, 2007). 
Kormchii, L., 'Zabytoe oruzhie [A forgotten weapon]', Pravda 17th February 1918/ No. 28 p.3. Detskaia literature 1967, 7, pp. 18-19.

Korolenko, V., Moe pervoe znakomstvo s Dikkensom (1912) in Sobranie sochinenii v 6 tomakh (Moscow: Gosudarstvennoe izdatel'stvo khudozhestvennoi literatury, 1954), V, pp. 364-371.

iamaglika., 'Moe pristrastie k Dikkensu.' Livejournal, 14 January 2013, $<\underline{\text { http://iamaglika.livejournal.com/31897.html?thread }=746137>}$, [accessed: 1 November, 2016].

Morozova, N., Moe pristrastie k Dikkensu: semeinaia khronika. XX vek. (Moscow: Moskovskii rabochii, 1990).

Sviatopolk-Mirskii, D. P., 'Korolenko' in Istoriia russkoi literatury s drevneishikh vremen po 1925 god (1926) (London: Overseas Publications Interchange, 1992).

Tolstoi, L., Dnevniki 1847-94 in Sobranie sochinienii v 22 tomakh (Moscow:

Khudozhestvennaia literatura, 1984) XXI.

Tolstaia, T., 'Mirovaia literature: krug mnenii. Tat'iana Tolstaia, pisatel'nitsa' in Inostrannaia literatura 9 (Moscow, 1999), pp. 238-247.

Zorin, A., 'Nelli Morozova. Moe pristrastie k Dikkensu' in Znamia 4 (Moscow, 2012).

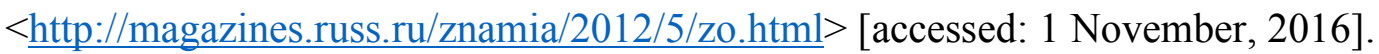

